\title{
O PROCESSO HISTÓRICO PLATINO NO SECULO XVII: DA ALDEIA GUARANI AO POVOADO MISSIONEIRO.*
}

\author{
Arno Alvarez Kern**
}

\section{INTRODUÇÃO}

A transformação cultural que leva as populações de índios guaranis ou guaranizados de suas aldeias, inseridas nas florestas tropicais e subtropicais atlânticas, ao novo espaço aberto com a instalação de povoados missioneiros, foi um processo histórico de transição da Pré-História para a História, motivado por uma situação criada pelo avanço das Frentes de expansão do colonialismo luso-espanhol americano. Esta agressão sócio-política das populaçбes brancas ibéricas gerou um processo de transculturaçđo, no qual jesuŕtas e guaranis foram os protagonistas principais. Este processo de transformações culturais ainda nao foi devidamente estudado e pode nos dar respostas mais seguras para entendermos certas especificidades dos povoados missioneiros, incompreensíveis a luz das teorias em voga, por demais europocêntricas.

As pesquisas levadas a efeito para a ebaloraçao de trabalho sobre a organização política das Missões jesuítico-guaranis ${ }^{1}$ deram origem a este problema de extraordinária importância para a compreensão do fenômeno missioneiro.

Os agentes do processo histórico que se desenvolveu na bacia platina oriental durante o século XVII foram atores e autores inseridos em um momento histórico complexo, no qual as frentes de expansao espanhola e portuguesa geraram uma fronteira tensa e viva, nao apenas entre si, mas igualmente face às populaçðes indígenas locais. Reis, funcionários administrativos, tais como Vice-Reis e Governadores, mercadores, bispos, encomendeiros, bandeirantes, jesuítas e indígenas foram atores e autores neste processo histórico. Dentre todos estes personagens históricos, os jesuítas foram os que mais se destacaram como agentes do processo de mudança sócio-cultural 
porque passaram as comunidades indígenas. Sua açao civilizadora não se resumiu na tarefa evangelizadora, mas foi igualmente responsável pela implantaçđo de valores e elementos materiais da sociedade ocidental européia da época. "A ação desenvolvida pelos missionários foi (...) civilizadora, pois nas Reduçбes foram implantados valores ño indígenas. O comportamento das pessoas e dos grupos' da sociedade tribal guarani estava orientado por valores muito diferentes dos da sociedade espanhola ou mesmo da Companhia de Jesus. Os indígenas não optaram livremente por todos os valores da sociedade ocidental européia, que os jesuŕtas representavam. Para alguns destes traços culturais, como a tecnologia do ferro, por exemplo, houve uma transmissão desejada pelos indígenas. Mas outros valores foram transmitidos de maneira autoritária, por decisões que se transformaram em obrigações, como é o caso da aceitação da vassalagem ao monarca espanhol, do pagamento do tributo ou da instalação do Cabildo, segundo o modelo espanhol. Eram condiçбes 'sine qua non' para a libertação do serviço pessoal e da escravidao".' Esta ação civilizadora levou as populações contactadas a passarem da idade da pedra à idade dos metais, a entrarem em contato com a escrita, a se inserirem na organização política complexa da monarquia absolutista, espanhola, a se familiarizarem com a tecnologia européia, como o exemplifica o uso do arado e a construção arquitetônica de templos barrocos, e mesmo uma limitada inserção no capitalismo mercantilista colonial. Vistos possivelmente como novos "heróis civilizadores" pelos grupos indígenas reduzidos aos povoados missioneiros, os jesuftas protagonizaram um processo de europeização parcial no qual muitos valores da antiga sociedade tribal foram mantidos. "A Miss๔o representou a reunião de diversas tribos numa mesma comunidade social, onde os elementos culturais guaranis passaram a coexistir com novos elementos, cristaos e ocidentais europeus. Se inicialmente ainda predominaram os elementos tradicionais, gradualmente os jesuítas foram introduzindo novas formas artísticas, novos rituais, uma economia mais produtiva e uma nova organização política". ${ }^{3}$

A vista das ruínas dos templos e dos remanescentes da escultura e pintura do barroco missioneiro nos fazem muitas vezes esquecer que este processo de transformaçбes culturais foi menos ocidentalizador do que se imagina, na medida em que inúmeros traços culturais das sociedades tribais permaneceram como elementos importantes nos povoados que se estruturavam.

Muitos mitos e falsas interpretaçбes envolvem o processo histórico platino, relativo às Missðes Jesuítico-guaranis, impregnando a bibliografia antiga e recente. Erroneamente, estes povoados missioneiros foram rotulados de "império", "república", "reino", "teocracia", "socialimo", "comunismo", etc, em análises superficiais e contrastantes com a própria documentação existentes. Como a dismitificaçao do mau uso destes conceitos já foi reali- 
zada anteriormente, ${ }^{4}$ ño pretendo abordar aqui este aspecto da questao. Apenas lembrar que "a inexistência de separaçao jurídica e política dos Trinta Povos em relação à sociedade global espanhola impede que se possa fazer cogitaçōes sobre a possibilidade de ter a organizaçao política local realizado uma experiência de cunho socialista ou comunista, no sentido moderno dos termos, no seio de uma economia de capitalismo mercantilista. Nem poderia ter sido objetivo da ação política desenvolvida pelos missionários, nos Trinta Povos, implantar este tipo de política econômica, a partir de um regime misto de propriedade, de um comércio de exportaçđo voltado para a economia colonial e uma visão de mundo crista ". 5

Mas além deste problema de método, outros ainda tornam difícil a reconstruçao histórica do período: a deformação dos dados etno-históricos e a adaptação dos dados a concep̧̧бes prévias da sociedade e da história. A mistificação torna-se ainda mais grave, quando as descriçðes se subordinam a certos discursos sobre a sociedade, gerando as tradicionais visões de inferno ou de paraíso que se encontram na bibliografia missioneira, características de um maniqueísmo histórico, nada científico.

Por outro lado, as análises tradicionais utilizam algumas teorias, atualmente em voga, que têm demonstrado suas utilidades nas interpretaçбes setoriais da história latino-americana, mas que sao insuficientes para equacionar o problema na sua totalidade e complexidade. É o caso das análises embasadas em teorias positivistas, de "tipos ideais", economicistas, marxistas vulgares, mecanicistas e/ou tecologicistas. Estas análises estao muitas vezes mais preocupadas em adaptar os documentos à teoria do que relacionar dialeticamente documentos e teorias, sem falsear os primeiros e revisando sem cessar as segundas. Só assim a pesquisa pode acrescentar algo mais à ciência, sem se degradar em teologia. Alguns pensadores são incapazes, como bem o demonstrou Clastres, "de refletir sobre o homem das sociedades primitivas sem incluí-lo nos contextos éticos e conceituais provindos do capitalismo ou da crítica do capitalismo. Sua etnologia da miséria nos faz perceber a miséria de sua etnologia". 6

Podemos exemplificar isto, a partir de um problema fundamental que caracteriza um dos aspectos deste processo complexo de transição das aldeias guaranis aos povoados missioneiros. É o problema, muito bem levantado|por Pierre Clastres, da transição da sociedade primitiva para sociedades dominadas pelo Estado. "As sociedades primitivas são sociedades sem Estado porque, nelas, o Estado é impossível. E, entretanto, todos os povos civilizados foram primeiramente selvagens: o que fez com que o Estado deixasse de ser impossível? (...) Que formidável acontecimento, que revolução permitiram o aparecimento da figura do Déspota, daquele que comanda os que obedecem? De onde provém o poder político? Mistério, talvez provi- 
sório, da origem". ${ }^{7}$ Uma das explicaçoes metafísicas, em voga, da ênfase às revoluçఠes tecnológicas, impulsionadas por "leis" inerentes ao próprio processo de transformaçбes dos meios de produção, responsáveis pela própria evolução teleológica da História da Humanidade. ${ }^{8}$ Este materialismo tecnologicista aponta a técnica como elemento determinante da causalidade que origina as mudanças históricas, na transição das sociedades primitivas préhistóricas, para as civilizaçōes históricas.

No caso específico das aldeias guaranis, nao foi um processo de modificaçø̄es endógenas - como o que se imagina ter ocorrido, quando das transformações das aldeias neolíticas do Oriente Próximo em cidades das civilizaçס̄es sumeriana e egípcia - que atuou como elemento de mudança. Mas sim, predominantemente, uma pressão externa, representada pelo imperialismo luso-espanhol e especialmente a ação civilizadora dos jesuítas espanhóis. Esta ação sócio-política irá gradualmente provocar uma integração cultural limitada e nao terá maior sucesso na integraçao econômica. Por outro lado, esta transiçao de grupos, emergentes de uma situação de "neolítico tropical" pré-histórico para os povoados missioneiros, nao pode ser explicada a luz da "transição do feudalismo para o capitalismo" ou do modelo de "escravismo colonial", tão em voga na bibliografia da História do Brasil Colônia. O processo platino tem nas Missões Jesuítico-guaranis algumas especificidades que parecem ser muito semelhantes ao fenômeno missioneiro do restante da América colonial e que tem sido relegado a um plano muito modesto, apesar de ser importante do ponto de vista teórico, na medida em que permite testar as interpretaçбes em voga.

A complexidade do processo histórico platino exige uma análise multi-variável e multi-causal, única capaz de superar o âmbito estreito e simplista de abordagens pretensamente rotuladas de "idealistas" e de "materialistas", mas que ignoram a complexidade das etapas do processo de análise histórica, como já foi discutido em outras oportunidades. "O conhecimento limitado que muitos historiadores demonstram em relação às teorias e aos esquemas "Idealistas" e "Materialistas", que utilizam de maneira insuficiente e pouco lógica, tendem a criar, muitas vezes, lamentáveis confusões, pois levam a simplificaçø̃es enganadoras, afastando a investigaçđo do campo, já relativo da ciência, e desviando a análise pelo terreno ilusório dos posicionamentos doutrinários. Talvez nunca seja demasiado recordar que - ao contrário das doutrinas - a ciência não é um corpo de conclusões fixas e indubitáveis, mas sim um somatório de resultados nao definitivos de um contínuo processo de investigação, no qual está sempre presente um método intelectual de crítica". 9 Apenas uma nova abordagem interdisciplinar e que leve em conta os conhecimentos e teorias da Antropologia, da Etno-história, da Arqueologia e da História, entre outras, poderá tentar, com algum sucesso, 
a reconstrução deste processo histórico tđo complexo.

A atual pesquisa ainda se encontra em desenvolvimento, e o presente artigo tem como finalidade apresentar alguns resultados preliminares. Devido a isto serão apresentados com maior ênfase algumas interpretaçбes sobre os aspectos sócio-políticos e tecno-econômicos do processo, sendo outros aspectos relacionados à religiao ou à arte apenas sugeridos.

\section{AS MUDANÇAS NA ORGANIZAÇÃO SOCCIO-POLITICA}

\subsection{O sistema político tribal. ${ }^{10}$}

Mesmo que a documentação histórica indique uma certa diversificação de grupos indígenas, reduzidos nas Missð̃es conhecidas como os Trinta Povos, iremos aqui nos referir apenas aos Guaranis, ño apenas por terem sido a maioria da população missioneira, mas igualmente por falta de dados sobre as demais tribos. Os grupos indigenas conhecidos como Guarani tinham na figura do "Tubichá" um elemento social de integraçao. Este cacique tinha como funçбes de seu papel a resolução de litígios internos e a liderança da tribo, tanto em tempo de guerra como de paz. Palavra e carisma formam a base, sobre a qual repousa o seu prestígio. A riqueza da expressão verbal e o saber falar são considerados atributos essenciais de sua liderança. Pertinente, tanto para as tribos sul-americanas como para as da América do Norte, é o esquema de tripla qualificação necessário ao cacique, ao líder tribal detentor da funçđo política: a) o chefe é um fazedor de paz, ou seja, a instância moderadora do grupo; b) ele deve ser generoso com seus bens, sem que se possa livrar dos pedidos de seus guerreiros; c) pode ascender à chefia somente um bom orador. ${ }^{11}$

Devia igualmente o cacique conhecer a tradição e escutar o conselho dos anciãos ou chefes das grandes familias que integram uma tribo. A liderança tribal era hereditária, e o desempenho à função de cacique dava direito à poligamia, um dos privilégios mais importantes do cargo. Em inúmeros casos, o cacique é igualmente o pajé, ou médico-feiticeiro do grupo tribal. Neste caso, o seu prestígio como xama ou pajé ("carar") aumenta a base de seu prestígio como cacique. Assim, na sociedade tribal dos guaranis, não era desconhecida esta síntese de poder político e religioso, representada pela conjunção de dois papéis sociais ("tubichá" e "carấ") em uma mesma pessoa. E possível que estivesse em curso entre as tribos guaranis um processo de centralização nas mãos dos “carar", tanto das funçб̄es religiosa e política? Talvez este fato possa explicar o sucesso dós jesuítas na substituiçao dos antigos pajés, na liderança das tribos indígenas, marcando "o 
advento de uma forma de poder político, à qual já tendiam as sociedades tupis-guaranis, mas que, sem dúvida, nao teriam realizado, por terem desenvolvido, juntamente com o profetismo, uma religião que recusava tal poder". 12

A aliança jesuíta-cacique foi fundamental para a Missðo. No decorrer do processo histórico platino, a cooptação pelos missionários jesuítas dos caciques guaranis foi um elemento importante na luta que travaram contra os pajés, o mais sério obstáculo à cristianizaçđo. Além da liderança política, os caciques deveriam ter na generosidade uma outra base de sua autoridade, além do talento oratório. Generosidade e o dom da oratória não eram apenas idiossincrasias do desempenho individual, mas propriedades formais da instituiçao do caciquismo. $\mathrm{O}$ desempenho deste papel social tinha diversos limites, dentre os quais a açđo dos próprios "carấ", a ausência de poder real e efetivo político e a própria obrigação da generosidade, pois o cacique apenas dá à tribo, sem nada poder pedir em troca.

"A contradição entre a solidão do chefe e a necessidade de ser generoso resolve-se igualmente através da poliginia. Se, em grande número de sociedades primitivas, a regra monogâmica prevalece amplamente, a pluralidade de esposas é, por outro lado, quase sempre um "privilégio" dos homens importantes, isto é, dos líderes. Mais do que um privilégio, a poliginia dos chefes desvenda-se como uma necessidade, na medida em que constitui para eles o principal meio de agir como líderes. A força de trabalho das esposas suplementares é utilizada pelo marido tendo em vista produzir os excedentes de bens de consumo que ele distribuirá à comunidade". Ou seja, na sociedade primitiva, a economia "é apenas um meio de política". ${ }^{13}$

A documentaçăo etno-histórica parece indicar para os séculos iniciais da colonização uma tendência à criação de federaçoes tribais, com a reunião de diversos caciques. "Já havia uma tendência entre os Guaranis à formação de aldeias mais amplas, como o próprio nome Tape parece indicar. Mas, este não era ainda um traço cultural de todas as tribos, pois algumas aldeias ainda eram constituídas de poucas casas. Nas aglomeraçðes mais amplas, onde havia já muitos caciques, fortalecia-se o papel político do Cacique Principal". ${ }^{14} \mathrm{O}$ mesmo vai acontecer posteriormente, quando da reuniao de diversas tribos nos povoados missioneiros. Se havia caciques com interesses em formar aldeias maiores e mais fortes para arrostar as ameaças, é possível 
pensar que "um chefe guarani de prestígio ou ambicioso podia encontrar no missionário e na Redução, que este trazia, um aliado virtual para seus propósitos, o que por sua vez servia também para o plano missionário". 15

Neste caso, uma assembléia rudimentar ou conselho passava a se constituir, formado por diversos caciques e chefes das famflias extensas. $\mathrm{O}$ conjunto passava a ser dirigido por um grande cacique e diversos caciques menores. Resta ainda saber se este era um desenvolvimento normal entre os guaranis ou a resultante da agressão do imperialismo luso-espanhol. De qualquer maneira, este fato explicará a coexistência no povoado missioneiro de um grande número de caciques, sem choques de liderança.

\subsection{O sistema político missioneiro}

Uma complexa teia de relaçóes políticas inseriram o caciquismo à estrutura do governo hispano-americano. Por um lado, as relações administrativas relacionaram os caciques aos Cabildos municipais e estes aos Governos Provinciais do Paraguai e do Prata, e, portanto, à Audiência de Charcas, ao Vice-Reinado do Peru e à monarquia espanhola. Por outro lado, uma teia de relações religiosas integrava os guaranis dos Trinta Povos ao papado, pois cada Missão se transformou em uma Doutrina (ou seja, uma paróquia) a partir de 1655 e cada missionário em um Cura ou pároco. Assim, as trinta paróquias missioneiras e seus curas estavam relacionados aos Bispados de Assunçao e de Buenos Aires, aos Arcebispos de Lima e a Santa Sé. Os jesuítas, novos líderes dos guaranis missioneiros, estavam ligados inevitavelmente à Companhia de Jesus, ou seja, aos seus superiores locais e ao Padre Geral, em Roma. Mesmo estas autoridades religiosas, quando instaladas em território americano, eram controladas pelo rei espanhol, através da instituiçao do Real Patronato. ${ }^{16}$

Estas relaçбes de obediência e comando estavam regulamentadas por um conjunto de normas religiosas e políticas estruturadas na legislaçao do Conselho das Indias, estabelecidas pelas Cédulas Reais e mesmo por regulamentos internos dos Trinta Povos, datados de 1637 e 1689. Ao contrário do que se poderia pensar, entretanto, muitas destas normas foram estabelecidas em função da realidade indígena e do gradual conhecimento que se passava a ter de seus costumes. Desta maneira, as Cédulas Reais de 1565 e de 1598, de Felipe II, já estabeleciam a existência do Tupambaé, ou seja, de "una masa de bienes comunes", ao lado dos bens particulares (Abambaé). Estas determinações foram acrescentadas a "Recompilación" das Leis das Indias (Lei 14, Título 4, Livro 6), obrigatórias para todo o mundo colonial espanhol. "Como se percebe, tanto a legislaçao espanhola anterior, como a organização social das tribos Guaranis e a própria concepção da Companhia 
de Jesus se entrelaçam num somatório de elementos diretivos que culminaram na institucionalizaçđo do Tupambaé" ${ }^{17 .} \mathrm{O}$ "Abambaé" nunca existiu como "propriedade privada" voltada para a produçđo, nas trilhas Guaranis. Foi sempre, isto sim, uma propriedade familiar nos moldes do que Chayanov denominou de "sistema de produção doméstica de consumo". ${ }^{18}$ Esta propriedade das famílias que se reuniam em torno de um cacique, ou seja, do "administrador do conjunto de propriedades familiares, o que constituiria a propriedade cacical, será considerada por alguns autores um modelo de propriedade privada, instituído pelos jesuítas em função de ordenações reais. $\mathrm{O}$ que é, no mínimo, uma afirmação que demonstra uma análise muito superficial do problema e parte de um erro inicial que é o de imaginar que em toda a História da Humanidade, e nesta riqueza incomensurável de povos e culturas, apenas existem dois tipos de propriedades, a coletiva e a privada.

A situação fronteiriça das Missóes e a sua situação de zona atacada pelas bandeiras escravagistas, assim como a possibilidade de escravismo devido aos encomendeiros espanhóis, levaram os jesuftas a imaginarem uma situação nova que poderia criar um espaço missioneiro de liberdade. A teia de relações políticas viu-se assim acrescida de um novo elemento, ou seja, a vassalagem direta dos guaranis ao rei espanhol, na medida em que eram guardiães da fronteira ameaçada pelo expansionismo luso-brasileiro. Esta submissão ao poder da monarquia absoluta implicava no pagamento de tributos à coroa espanhola (um peso de oito reales por homem adulto), bem como a manutenção de uma situação de vigilância e defesa da fronteira como tropa auxiliar. Este último dado novamente demonstra a complexidade deste fenômeno de transformaçбes culturais, pois os guerreiros guaranis permaneciam armados com suas armas tradicionais, as quais se acresciam mais de seiscentas bocas de fogo (mosquetes e arcabuzes) com a respectiva munição.

Finalmente, restaria ainda recordar que, se por um lado a influência espanhola introduzia o municipalismo na sociedade indígena na forma do Cabildo colonial, este ensaio de aculturação política novamente demonstra a complexidade da transformação, pois os varistas ou cabildantes eram caciques guaranis, com o título nobre espanhol de Dom.

"Qual teria sido o papel exato desta organizaçao política de dupla origem, indígena e hispânica? Teria sido um instrumento que devia regulamentar e manter estruturas préexistentes? Levando-se em conta que os Trinta Povos não cessaram de se transformar, no decorrer do século XVIII, desde o estágio inicial de aldeia indígena visitada por um missionário, até as grandes Doutrinas do início do século 
XVIII, percebe-se que uma gama de relaçóes polfticas implantadas pouco a pouco estiveram antes a serviço da mudança do que da estagnação. Desempenharam de maneira eficaz as funçбes básicas de qualquer organismo político, garantindo a segurança externa, mantendo a ordem interna e sendo um ótimo instrumento de progresso". ${ }^{19}$

A liderança no interior da organizaçđo política missioneira ficou igualmente dividida entre os diversos caciques e o jesurta. Este último foi admitido junto às comunidades guaranis em lugar do antigo médico-feiticeiro, ou pajé ("carai" ou "pagy uaçu"), graças fundamentalmente ao seu prestígio e carisma. Mesmo posteriormente, quando o carisma individual foi substituído pelo carisma da função, o poder de conceder a salvação e o conhecimento imenso, que demonstravam, faziam com que seu prestígio os associasse ao prestígio dos caciques. Ambos tinham o dom da oratória e desempenhavam papéis importantes na soluçao dos problemas e litígios internos, bem como punham em prática as políticas de seus superiores, quer fossem autoridades jesuíticas, bispos ou governadores.

Tanto para a açao missionária, como para a ação civilizadora, a aliança estabelecida entre caciques e jesuítas foi decisiva do ponto de vista político. "Tem sido muito ignorada a importância deste fato, quase sempre substituído por explicaçбes que se embasam numa situação de infantilismo do indígena ante o missionário. A belicosidade das tribos Guaranis, ainda em fase de ataques contra os núcleos de colonização hispânica, e a própria situação de crise étnica e de messianismo, fizeram com que o ambiente encontrado pelos jesuítas fosse de insegurança, mas, ao mesmo tempo, de violência instável. Alguns missionários pagaram com a vida por isto. Mas, por outro lado, as lideranças tribais pareciam divergir quanto às soluçбes a serem postas em prática. Enquanto os pajés exorcizam seus demônios, ameaçam com visões de fim de mundo e propб̄em a partida para a busca sofrida da "terra sem mal", os caciques tentam levantar a coragem dos guerreiros para ataques aos núcleos de colonização ou às frentes de expansão, nos quais as derrotas ante as armas de fogo são decepcionantes e humilham toda uma tradiçăo de conquistas e expansão passadas. É neste quadro histórico sombrio que a proposta dos jesuítas irá tombar como uma solução política possível: o pacto com a sociedade branca, através da vassalagem direta ao monarca espanhol". ${ }^{20}$ 


\section{AS TRANSFORMAÇOES TECNO-ECONOMICAS}

\subsection{Sistema de produç̃o doméstico de consumo tribal guarani}

Durarite muito tempo se manteve uma visão tradicional da economia tribal que indicava uma situação de miséria, dificuldades e fome, devido às características de subdesenvolvimento técnico, impossibilidades de formação de estoques e de subsistência. Esta visão do problema sofreu recentemente uma profunda mudança com a ampliação das análises. Em função do reestudo de milhares de dados coletados recentemente pela Etnologia, percebe-se que "não somente a economia primitiva não é uma economia da miséria, mas que ela, ao contrário, permite determinar a sociedade primitiva como a primeira sociedade de abundancia". ${ }^{21}$ Os estudos desenvolvidos por Marshall Sahlins não apenas comprovam que as economias primitivas se caracterizam por esta "abundância primitiva", mas igualmente destacam serem estas economias domésticas de consumo "sub-produtoras". "Tanto agrícolas, como pré-agrícólas, elas parecem, na maiơria, ignorar suas próprias capacidades econômicas. A mão-de-obra é sub-empregada, os meios tecnológicos são sub-desenvolvidos, os recursos naturais sub-explorados". 22

Ao contrário de nossa economia, os grupos indígenas produzem para viver, mas não vivem para produzir. Ao lado de uma divisão sexual do trabalho, a produção é segmentária, apenas para o consumo e o acesso aos meios de produção é autônomo. Assim, uma características básica deste sistema doméstico ou familiar de consumo é a utilização pouco intensiva das forças de produçao. Este sistema doméstico não possui normas de subsistência limitadas apenas em termos absolutos, mas inclusive em relaçao ao próprio potencial da sociedade. De fato, quanto maior a capacidade de trabalho do grupo familiar, ou da grande casa, menos trabalham seus integrantes. Esta constatação foi pela primeira vez enunciada por Chayanov. ${ }^{23} \mathrm{Na}$ medida em que as unidades de produção são as familias e não a tribo, este tipo de produção é segmentário, anárquico e com tendências à dispersão em caso de crise, quando cada família procura entao sobreviver sozinha. 0 que fornece a integração a esta economia e favorece as relaçб̄es centrífugas é a política, ou seja, o caciquismo e a autoridade dos anciđos.

Sinteticamente, podemos afirmar que as orientaçбes desta economia primitiva podem assim ser expressas, segundo Sahlins: a economia se concentra preponderantemente na alimentaçđo e não depende nem de uma tecnologia complexa, nem de uma complexa divisão do trabalho; a economia previlegia a produção doméstica, familiar, ou seja, tem na casa sua unidade de produção $($ casa $=$ família extensa $)$, a divisđo do trabalho é por sexo, a auto- 
ridade se deve à idade, a produção se destina a satisfazer as necessidades do grupo familiar e este tem acesso direto aos recursos estratégicos. $\hat{\mathrm{E}}$, finalmente, uma ordem social onde o direito do controle sobre os produtos caminha lado a lado com o direito de explorar os recursos produtivos, onde o comércio de título é restrito e os privilégios da opulência nada provam. ${ }^{24}$ Como estas afirmaçбes gerais poderiam ser adaptadas ao sistema doméstico de produçao dos Guaranis?

No caso específico dos Guaranis, estamos frente a padróes de subsistência tribal inseridos no ambiente das florestas tropical e subtropical. A sua horticultura se caracteriza pelo sistema de corte e queimada (coivara) e pelo nomadismo agrícola nas várzeas dos rios. Assim, é no interior da floresta, em clareiras abertas, que se plantavam o milho ou a mandioca numa espécie de horta muito diferente da agricultura de campo aberto, típica dos camponeses europeus. Este sistema tradicional nas florestas tropicais e sub-tropicais da América do Sul parece ser capaz de alimentar populaçбos aldeđs da ordem de 450 pessoas, enquanto que em toda esta enorme região a média das comunidades de horticultores não ultrapassa geralmente 150 pessoas, conforme os estudos desenvolvidos. ${ }^{25}$

No decorrer do século XVII o espaço ocupado pelas aldeias guaranis entrou em franca diminuição, devido aos avanços dos encomendeiros espanhóis e aos ataques dos bandeirantes paulistas. Os primeiros documentos históricos sobre os guaranis contactados pelos brancos ibero-americanos atestam uma crise que se traduzia, muitas vezes, em penosas e longas peregrinações lideradas pelos pajés em busca da "terra sem mal." Durante algum tempo se pensou que estas longas marchas, em que a aldeia tudo abandonava, se deveriam a uma pressão demográfica, pois a população teria se desenvolvido demais dentro das manchas de floresta sub-tropical da América do Sul temperada atlântica. Entretanto, mesmo que algumas aldeias tenham se estabelecido em zonas de encostas pouco férteis, como se as zonas mais favoráveis já estivessem ocupadas (como o demonstram os últimos estudos arqueológicos), não podemos ignorar que os avanços das frentes de aça colonizadora luso-espanholas colocaram estas populaçбes em um extremo perigo de sobrevivência cultural e étnica, pois o genocídio indígena tendia gradualmente a se incrementar.

É evidente que os padróes de subsistência dos guaranis inclúam ainda a caça e a coleta. Estas atividades sempre foram muito intensas e oportunizavam abundante alimentaçđo. Exigiam a ocupaçæo de territórios amplos e deslocamentos sazonais de maior porte do que os exigidos pela horticultura, pois o esgotamento dos produtos da caça e da coleta obrigam a mudanças da aldeia mesmo quando o solo ainda fértil para os roçados. Com o avanço das frentes de colonização, este espaço se limitava de maneira inexorável, tor- 
nando a crise profunda e sem soluçбes. Como as pesquisas de Sahlins demonstraram muito bem e os dados conhecidos sobre a crise do mundo guarani o confirmam, é no caso de uma conjuntura histórica onde se multiplicam as contradiçбes externas que a situação crítica pode se desenvolver em fenômenos de destruiçāo e de transformação. As normas do sistema de produção doméstica de consumo das economias primitivas tendem à inércia, à manutenção da tradiçăo, e por isto se explica porque predominam as normas moderadas de produção costumeira de subsistência. ${ }^{26} \mathrm{O}$ choque com as frentes colonizadoras, especialmente com a expansão das expediçбes escravagistas dos bandeirantes e dos encomendeiros espanhóis, geraram uma situação crítica favorável à desagregação das tribos em pequenos grupos familiares que buscavam esconder-se no âmago das florestas, ou nas encostas dos fales fluviais onde o terreno pouco fértil trazia problemas drásticos para a sobrevivência.

As forças centrífugas de cada unidade familiar de produção se acentuam quando agressōes externas ou calamidades naturais ocorrem, levando este sistema à desagregação; os grupos familiares se isolam e a comunidade se atomiza. ${ }^{27}$ Esta desagregação coloca em perigo uma das mais extraordinárias características deste sistema doméstico: a reciprocidade. A doação gratuita dos bens e dos alimentos é um dever de cada um e o privilégio de todos, no regime de reciprocidade.

E esta reciprocidade solidária e constante que anula as forças centrífugas dos grupos doméstico de consumo e permite a autonomia completa dos grupos tribais e das aldeias. Cada um dá e ganha tudo de todos. Esta situação se estabelece ño apenas entre os indivíduos e as famílias, mas igualmente nas relaçбes entre os caciques e seus comandados. Entretanto, para manter seu prestígio, o cacique deve redistribuir bens em muito maior número do que os que recebe. Isto só é possível pela manutenção da instituição da poligamia cacical. Desta maneira, a economia indígena se articulava em termos de reciprocidade e de redistribuição dos bens e alimentos, num solidarismo constante. A redistribuição constitue, do ponto de vista social, de uma relaçao no interior mesmo do grupo, caracterizando-se por ser uma ação coletiva. Já a reciprocidade é uma relação entre componentes dos grupos, ou seja, açбes e reaçбes entre as partes do todo. ${ }^{28}$

Outra característica desta economia era a propriedade cacical. Uma vez estabelecida a aldeia no novo território, após a mudança periódica, cabe ao cacique a distribuição das porçōes de terra a famílias que irão trabalhar instalando as roças de mandioca ou de milho, plantando o fumo, as cabaças, os feijós, etc. A administração do chefe se fará sobre os produtores, os quais possuem tanto os meios de produção como o produto de seu trabalho. É mediante o sistema de propriedade cacical e familiar que se estabelece 
uma produção horticultora. Esta situação diverge profundamente de nossos sistemas atuais, onde os proprietários dos meios de produção e dos produtos (burguesia capitalista ou "nomenclatura" do estado soviético) dominam política e economicamente os produtores, os quais recebem apenas salário.

Resumindo:

\begin{tabular}{|l|l|l|}
\hline $\begin{array}{l}\text { Propriedade } \\
\text { cacical e } \\
\text { famnlia }\end{array}$ & $\begin{array}{l}\text { Produtores } \\
\text { indigenas }\end{array}$ & $\begin{array}{l}\text { Meios de produção } \\
\text { e produto }\end{array}$ \\
\hline \begin{tabular}{l} 
Propriedade $\begin{array}{l}\text { burguesa ou da } \\
\text { "nomenklatura } \\
\text { comunista" }\end{array}$ \\
\hline
\end{tabular}
\end{tabular}

Nas sociedades tribais, portanto, a familia ou a casa conservam uma relação primária com o espaço a partir do qual obtém sua alimentação, mesmo que se possa afirmar que nem sempre esta propriedade sobre terrenos de cultura, de caça, de pesca ou de pastagens seja exclusiva, pois temos que recordar que o espaço tribal é a propriedade cacical. ${ }^{29}$

\subsection{Sistema de produção doméstico e comunitário dos povoados missioneiros}

Transformaçбes culturais de extraordinária importância assinalam a passagem das aldeias guaranis para as Missões Jesurticas, do ponto de vista tecno-econômico. ${ }^{30}$ Mas aqui, mais uma vez, é igualmente necessário e importante destacar o quanto da antiga economia tribal guarani permaneceu, tornando-se parte integrante da nova estrutura.

Uma mudança técnica fundamental foi a introdução do arado puxado por bois, o que provocou a substituição da antiga horticultura de corte e queimada, realizada no interior da floresta sub-tropical e tropical, por uma agricultura em moldes europeus realizada em campo aberto. Entretanto, os produtos produzidos continuaram em grande parte os mesmos e a propriedade continuou sendo o "Abambaé". Em outras palavras, as terras do povoado foram distribuídos entre os caciques para que administrassem os lotes familiares, como sempre tinham feito no interior da floresta. Entretanto, como cessou o nomadismo das aldeias, trocado que foi pelo sedentarismo da Missão jesuítica, as terras uma vez distribufdas passaram a ser sempre de cada uma das famflias. 
A proteína animal, anteriormente obtida pela caça, foi substiturda com proveito pela pecuária e pelo consumo em larga escala de carne bovina. Grandes rebanhos, enormes estâncias e as reservas de gado propiciadas pelas Vacarias do Mar e dos Pinhais, favoreceram uma alimentação rica e abundante.

A antiga coleta persistiu no extrativismo da erva mate, inicialmente nos ervais nativos e posteriormente em ervais artificialmente plantados. A produção de erva mate para a exportação foi fruto de um contrato social jesuítico-guarani, visando garantir a autonomia missioneira, pois possibilitava a importaçđo dos poucos elementos necessários.

Esta modernização ocorrida nos padrōes de produção e de subsistência terminou se refletindo igualmente no setor de mão-de-obra. Com o estabelecimento do "Tupambaé" e a produção coletiva em dois dias da semana, colocou-se a questao do trabalho extra-familiar, voltado para a comunidade. Não foi muito fácil esta transformação, pois a divisão por sexo que norteava a produção doméstica indígena passava a ser modificada. $\mathrm{O}$ arado puxado por bois exigia a força do braço do homem adulto no trabalho da lavoura, tanto no "Abambaé" como no "Tupambaé". Por outro lado, era difícil ao guarani entender certas reprimendas dos jesuítas que pensavam ser o indígena pouco dedicado ao trabalho. Enquanto os jesuítas nascidos na América (como Roque Gonzales) ou os de origem ibérica jamais criticam o ind ígena, os de origem austríaca ou alema (como o Padre Sepp) não compreendem a mentalidade guarani, para os quais a vida nao era para ser dedicada para a produção, mas para viver.

Por outro lado, e reciprocidade continuou a funcionar de maneira semelhante à da tribo guarani do período anterior a Redução. No seio do povoado missioneiro, a reciprocidade ao nível familiar e tribal continuou igual, estendendo-se mesmo as relaçбes entre os diversos povos. Ao nível familiar e tribal, esta reciprocidade foi generalizada. A solidariedade continua a ser, portanto, parte integrante nas relações entre os indígenas que compбem estas comunidades missioneiras. Nas palavras de Popescu, tratava-se de um "solidarismo puro, no sentido do estado de ânimo de todos os sujeitos econômicos e todas as suas várias categorias sociais, inclusive a dos missionários; e solidarismo de grande dimensão por tratar-se de um organismo de grande amplitude, tanto em sua extensão temporal como em seu volume demográfico..."31 Os contatos entre um povoado e os Trinta Povos, caracterizou-se por uma reciprocidade equilibrada, ainda mais acentuada nas relaçбes de trocas entre os Trinta Povos e a sociedade hispano-americana. E permaneceu em relação aos inimigos (portugueses, bandeirantes luso-brasileiros e indígenas Charruas ou Minuanos) uma reciprocidade negativa. 
Se a economia primitiva guarani era autônoma, esta situação permaneceu a mesma no povoado missioneiro, pois a inserçđo na economia colonial foi extremamente limitada, reduzindo-se a barcaça anual de exportação de erva mate. A produção missioneira continuou sendo sempre voltada para o consumo, sem visar mercados, como tinha sido sempre a economia tribal guarani. Mantinha-se assim a característica de autarquia econômica e de solidarismo interno.

A prática da reciprocidade foi igualmente acompanhada pela da redistribuiçđ̃o, no povoado missioneiro. Enquanto a propriedade do "Abambaé" fornecia às famńlias e tribos o necessário para a sobrevivência em boas condiçōes, o "Tupambaë" exigia um trabalho coletivo do indígena para a redistribuição, pois servia para suprir as eventuais deficiências da produção familiar ou atender as necessidades de todo o povoado em momentos de crise. O" "Tupambaé" substituiu a redistribuição cacical, conseguindo atender inclusive às necessidades do povoado em termos de produtos externos (muniçбеs, paramentos para os altares, etc).

Estas transformaçðes foram seguidas de outras ao nível da tecnologia. Introduziu-se a metalurgia do ferro, mas permaneceram as técnicas de lascamento e polimento da pedra. Desde o estabelecimento das primeiras Reduçбes, os jesuítas registraram a importância do ferro para os indígenas guaranis: "Y es cosa maravillosa y benigna providencia de nuestro Seffor, que dando á cualquiera indio una cuna de hierro (que vale dos pesos ó menos) para rozar el monte, luego está seguro, y como con grillos y cadenas para quedar-se para siempre en el pueblo y Doctrina, y hacerse cristiano; e asi dicen muy bien los Padres que las almas aquí valen á cufa de hierro". ${ }^{32} \mathrm{~A}$ cerâmica para uso diário ou para outras finalidades rituais, decorada plasticamente ou pintada, foi acrescida de elementos europeus, tais como bases planas, alças e asas, bem como uma decoraçao monocrômica. Igualmente aqui se percebe a coexistência de elementos indígenas ao lado dos de origem européia.

A teoria da "revolução tecnológica", muito em voga para explicar os processos de transformação sócio-cultural, principalmente pelos autores que defendem um determinismo tecnológico monocausal, não se aplica ao complexo conjunto de mudanças aqui examinado. As forças produtivas do sistema doméstico tribal de consumo nao tendem ao desenvolvimento e a economia se caracteriza pela sub-produção. $\hat{E}$ a sociedade que limita o campo econômico e exerce sobre ele sem cessar um controle rigoroso. Foi assim no estágio tribal anterior ao contato com os missioneiros jesuítas, continuou a ser assim no interior mesmo da economia missioneira, onde a política econômica continuou a exercer seu domínio. A economia não foi assim nunca uma "máquina" autônoma. ${ }^{33} \mathrm{O}$ processo de transformaçōes sócio-culturais 
que alteram os padrôes tecno-econômicos da aldeia guarani e que leva os indígenas a inserção parcial na sociedade global espanhola mediante a instalação dos povoados missioneiros parece se explicar melhor por uma gama de agentes de mudanças, dentre os quais as pressóes sócio-políticas das frentes de expansão colonizadora parecem exercer um importante papel.

\section{AS INOVAÇÕES NO CAMPO DAS IDÉIAS}

Poder-se-ia ainda sugerir uma série de transformaçøes ocorridas ao nível da religiao e das artes, visando um aprofundamento da análise deste complexo processo de mudanças.

O messianismo guarani e a crença na "terra sem mal" 34 foram assimilados sincreticamente ao pensamento religioso cristశo, com algumas alteraçбes significativas, como por exemplo a crença de que a terra sem mal nao poderia ser atingida em vida, mas seria um paraíso ao qual se tinha acesso após a morte.

Os antigos pajés foram substituídos pelos novos pajés-jesuítas que continuaram a afirmar ser Tupa um deus importante num panteão agora ampliado com a inserção de anjos e santos. "Métraux foi o primeiro a denominar os jesuítas de "novos pajés" dos Guaranis, destacando o caráter sagrado do papel que desempenharam ante os índios. (...) Apoiados numa tecnologia européia e fazendo parte de uma ordem religiosa extremamente organizada, os jesuítas demonstravam mais poder do que os mágicos indígenas, que agiam de maneira dispersa e somente tinham como poder aquele que lhes era conferido pelo prestígio pessoal". ${ }^{35}$

No interior da Missão Jesuítica, a vida religiosa se ampliou em festas de santos padroeiros e com o estabelecimento de Congregaçð̃es como as de São Miguel (para meninos e meninas com mais de doze anos e adultos de até 30 anos) ou da Santíssima Virgem (para os adultos com mais de trinta anos). Estas congregações compensavam a limitação imposta pela sociedade branca de acesso do líndio ao sacerdócio. Comunhơes mensais e eleições para prefeito e assistentes destas congregações enchiam a vida do povo missioneiro, substituindo as antigas bebedeiras rituais regadas a bebida fermentada de milho.

A educação pelá prática, típica da aldeia guarani, continuou a ser um elemento importante no povoado missioneiro, acrescida entretanto por um ensino básico de rudimentos da ciência européia para os filhos de caciques, fornecida pelo jesuíta no interior da igreja, juntamente com o ensino da língua espanhola. Danças, música, canto e artesanato, comuns na vida diária da aldeia guarani, tornaram-se mais complexos e amplos com a introdução 
de elementos culturais europeus. $\mathrm{O}$ teatro, a arquitetura e a escultura típicas do período do barroco europeu passaram a inovar o panorama artístico e cultural dos guaranis. A imprensa veio coroar esta série de transformaçø̃es e livros escritos por guaranis marcaram em mais um aspecto importante esta passagem da pré-história para a história, da condição de grupos sociais ágrafos para a situação de populaçōes missioneiras parcialmente letradas. ${ }^{36}$

\section{CONCLUSÕES}

Este processo de transição de grupos indígenas guaranis, horticultores de floresta tropical e sub-tropical, para uma situaçđo de gradual e limitada inserção cultural na sociedade hispano-americana parece demonstrar como são limitadas as possibilidades de aplicação de "tipos ideais" (marxistas ou não) europeus a fenômenos específicos da história latino-americana.

As análises de cunhos economicistas ou de determinismo tecnológico igualmente parecem se limitar a um reducionismo e à simplificação de complexos processos de transformação, as quais apenas se tornam mais compreensíveis se levadas em conta as múltiplas variáveis e a causalidade múltipla, caracterizada pela dialética global de todos estes elementos. As análises meramente políticas ou as descritivas e factuais são igualmente deficientes, impedindo pelo seu "positivismo" a compreensðo das complexidades do problema.

As ações e reaçбes de variáveis tais como espaço e paisagens geográficas, contexto social, atores em ação, estruturas tecno-econômicas e sóciopolíticas, aspectos artístico-religiosos, etc, indicam a necessidade de utilização de modelos complexos e análises multi-causais.

Entretanto, é necessário reconhecer as limitações desta abordagem aqui apenas sugerida. Torna-se necessária a ampliação da pesquisa na documentaçao para reunir dados mais precisos sobre este complexo processo de transiçāo. É igualmente necessário ampliar o conceito de documentação, de maneira a abarcar ño apenas as fontes escritas dos arquivos (tais como as da Coleçao de Angelis, por exemplo), mas igualmente as fontes de natureza material obtidas em escavaçбes arqueológicas a serem realizadas nos povoados missioneiros.

A confrontaçđo entre as informaçбes ainda ocultas nos arquivos documentais e aquelas ocultas sob os entulhos dos séculos nas ruínas missioneiras, deverá poder dar origem a uma nova produção histórica, mais completa e teoricamente mais verossível do que as atuais interpretaçбes.

A pesquisa não pode se limitar às fontes e metodologias históricas, mas deverá ser interdisciplinar, englobando metodologias e teorias específi- 
cas da Arqueologia, da Antropologia e da Etno-história.

Este vasto campo de estudos deverá ser ainda desbravado pelas futuras geraçбes de pesquisadores, dentre os quais a atual comunidade missioneira deverá reconhecer necessariamente cientistas locais. Na medida em que esta pesquisa é uma busca de raízes históricas para a sociedade regional e nacional, a responsabilidade passa a ser de todos. Por outro lado, a contribuiçăo teórica da pesquisa é de largo alcance, na medida em que serve de teste para as teorias em voga e oportuniza a elaboração de novas teorias explicativas, um elemento altamente estimulante no vir a ser da ciência social que denominamos de História.

\section{NOTAS}

1. KERN, Arno Alvarez. Missóes: uma utopia politica. Porto Alegre, Mercado Aberto, 1982 .

2. Idem, ibidem, p. 99.

3. Idem, Ibidem, p. 111.

4. Idem ibidem, capítulo 5 "A unidade política dos Trinta Povos". Ver também "O modelo político das Missões Jesuŕticas", nos Anais do 5 ? Simpósio Nacional de Estudos Missioneiros, de Santa Rosa, RS, 1985.

5. KERN, Arno Alvarez. op. cit, p. 264.

6. CLASTRES, Pierre. "A economia primitiva". In: Arqueologia da violência. Ensaios de Antropologia poltitica. São Paulo, Brasiliense, 1982. p. 144.

7. ClASTRES, Pierre. A sociedade contra o estado. Rio de Janeiro, Francisco Alves, 1978.p. 143.

8. Um exemplo é a obra de Darci Ribeiro,"O processo civilizatório"(Rio de Janeiro, Civilização Brasileira, 1968). Veja-se a análise crítica coerente desenvolvida por SHAW, William. Teoria Marxista da História. Rio de Janeiro, Zahar, 1979, p. 139-150.

9. KERN, Arno Alvarez. Tendências atuais da ciência histórica. Revista Ciéncias e Letras 2:61-68, p. 65, 1982.

10. Para aprofundar estes aspectos, ver as obras de Pierre Clastres citadas.

11. CLASTRES, Pierre, op. cit. nota 7, p. 23.

12. ClASTRES, Hélène. A Terra sem Mal. O profe tismo Tupiguarani. São Paulo, Brasiliense, 1978. p. 79.

13. ClASTRES, Pierre, op. cit. nota 6, p. 137.

14. KERN, Arno Alvarez, op. cit. nota 1, p. 110.

15. MELIÁ, Bartolomeu. Las Reducciones Jesufticas del Paraguay: un espacio para una utopia colonial. Estudios Paraguaios 6(1):161-62, 1978. 
16. KERN, Arno Alvarez, op. cit. nota 1, p. 248.

17. Idem, ibidem, p.74.

18. CHAYANOV, A. V. The theory of peasant economy. Homewood, R. Irwin, 1966. Citado em SAHLINS, Marshall. Age de pierre, age d'abandonance. L'économie des sociétés primitives. Paris, Gallimard, 1976. p. 82 e seguintes. $\mathrm{O}$ conceito está explanado na p. 134.

19. KERN, Arno Alvarez, op. cit. nota 1, p. 55.

20. Idem, ibidem, p. 109-10.

21. CLASTRES, Pierre, op. cit. nota 6, p. 130. SAHLINS, M., op. cit., p. 37 e seguintes.

22. SAHLINS, M. op. cit., p. 82.

23. Idem, ibidem, p. 131.

24. Idem, ibidem, p. 239-40. Obs: a tradução deste trecho é livre.

25. CARNEIRO, Robert. "Slash-and-burn agriculture: a closer look at its implications for settlement patterns", citadopor SAHLINS, M, op. cit., p. 89.

26. SAHLINS, M., op. cit., p. 132.

27. CLASTRES, Pierre, op. cit., nota 6, p. 133-34.

28. SAHLINS, M., op. cit., p. 241.

29. Idem Ibidem, p. 138.

30. Para a análise das características da economia missioneira, ver: MÖRNER, Magnus. The political and economic activities of the Jesuits in the La Plata region: the Hapsburg Era. Stockolm, V. Pettersons, 1953; POPESCU, Oreste. Sistema económico en las Missiones Jesuiticas - un vasto experimento de desarollo indoamericano. Barlona, Ariel, 1967; BRUXEL, Arnaldo. O sistema de propriedade das Reduçס̄es Guaranníticas. Pesquisas 3: 29-198, 1959; KERN, Amo Alvarez, op. cit. nota 1, "A política econômica" (segundo capítulo).

31. POPESCU, Oreste, op. cit., p. 97.

32. Carta Anua de 1618-19, do Padre Pedro de Onate. Citada em HERNANDEZ, Pablo. Organización social de las Doctrinas Guaranies de la Compañia de Jesus. Barcelona, G. Gili, 1913. vol. 1, p. 385.

33. CLASTRES, Pierre, op. cit., nota 6, p. 144.

34. CLASTRES, Hélène, op. cit.,p. 30, 79, 113-16.

35. KERN, Arno Alvarez, op. cit. nota 1, p. 105-6.

36. FURLONG, Guillermo. Missiones y sus pueblos de Guaranies. B. Aires, Imp. Balmes, 1962, p. 449 e seguintes.

*Trabalho apresentado nas "Primeras Jornadas Internacionales sobre las Misiones Jesuíticas" (Resistência, Chaco, Argentina), em 5 de setembro de 1984.

* Departamentos de História da Pontifícia Universidade Católica do Rio Grande do Sul. Porto Alegre. 